\title{
Large wood and flash floods: evidence from the 2007 event in the Davča basin (Slovenia)
}

\author{
F. Comiti ${ }^{1}$, L. Mao ${ }^{1,3}$, E. Preciso ${ }^{2}$, L. Picco ${ }^{1}$, \\ L. Marchi ${ }^{2} \&$ M. Borga ${ }^{1}$ \\ ${ }^{I}$ Department of Land and Agroforest Environment, \\ University of Padova, Italy \\ ${ }^{2}$ CNR - IRPI, Padova, Italy \\ ${ }^{3}$ Department of Geography, University of Hull, UK
}

\begin{abstract}
This paper presents the evidence gathered during a post-flood survey in a Slovenian mountain basin (Davča basin, drainage area of $32 \mathrm{~km}^{2}$ ) following the catastrophic flood of September 2007. Channel avulsion, debris flows and landslides delivered large volumes of wood into the channel, and massive wood accumulations were found at the basin outlet. Wood-induced dam-break flows were therefore hypothesised to be responsible for most of the damages. Field observations and approximate discharge estimations indicate that the damages suffered in the Davča basin can be attributed to excessive wood load only to a limited extent, and that the critical factors were narrow road crossings which acted as traps for sediment and wood.
\end{abstract}

Keywords: woody debris, flash floods, mountain rivers, Slovenia.

\section{Flood hazards due to natural dams and large wood}

Mountain valleys are subject to several natural hazards, which include mass wasting, debris flow and fluvial processes. However, some of the most hazardous phenomena occur when the three phenomena interact, as in the case of temporary damming of stream channels by landslides $[6,7,12]$ or debris-flow deposits which often include large wood (LW) $[1,8,10]$. In fact, the subsequent breaching and collapse of these dams release destructive dam-break waves which can attain extremely high flow discharges, unpredictable from a mere hydrological perspective [9]. As a consequence, such events are thought to 
represent the most effective and dramatic geomorphic phenomena in mountain channels [5]. Indeed, natural dam-break processes - transporting huge amounts of wood (Fig. 1) - have caused some of the largest damages in several valleys of the Dolomites (Italian Alps) during the 1966 catastrophic flooding [3, 4]. The extreme magnitude of floods caused by the failure of natural dams is matched by a typically low frequency $(>50-100 \mathrm{yr})$, such that these events may be easily forgotten, thus allowing unwise human occupation of flood-prone corridors. This paper presents a qualitative analysis of the geomorphic processes triggered by an intense flash flood occurred in a mountain basin of the Slovenian Alps, which featured considerable LW transport and deposition. The underlying hypothesis is that the extreme water stages observed and the damages could be ascribed - at least partially - to the collapse of temporary dams formed by sediments and LW.

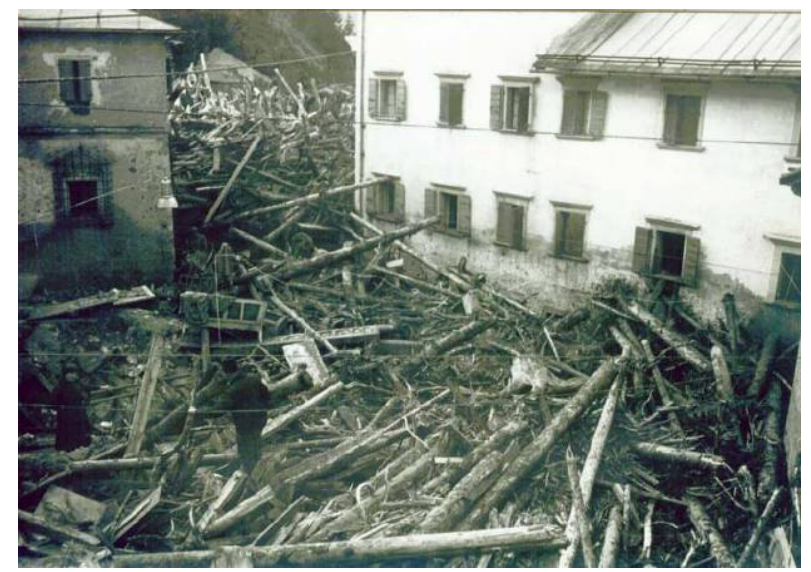

Figure 1: $\quad$ Huge volumes of wood were transported along the Fiorentina river and invaded the small town of Caprile (Italian Alps) during the 1966 flood (R.I. >100 yr).

\section{The flash flood of September 2007 in Slovenia}

On $18^{\text {th }}$ September 2007, there was widespread flash flooding in Slovenia. The flooding caused seven casualties and about $€ 300$ million of damages. The precipitation featured a convective bands structure and extremely large rainfall gradients. The consequence of such precipitation pattern was that nearby small basins responded in sharply different ways. The storm lasted for 10-14 hours, depending on locations. The cumulated precipitation ranged in most basins between 250 to $300 \mathrm{~mm}$. The storm led to a distributed flash flooding along the Sava and Selščica Sora rivers [2, 11].

\section{Study area and methods}

The study area is the Davča basin $\left(32 \mathrm{~km}^{2}\right.$, Fig. 2), one of the tributaries of the Selščica Sora river most severely hit by the flash flood $(230 \mathrm{~mm}$ of cumulated 


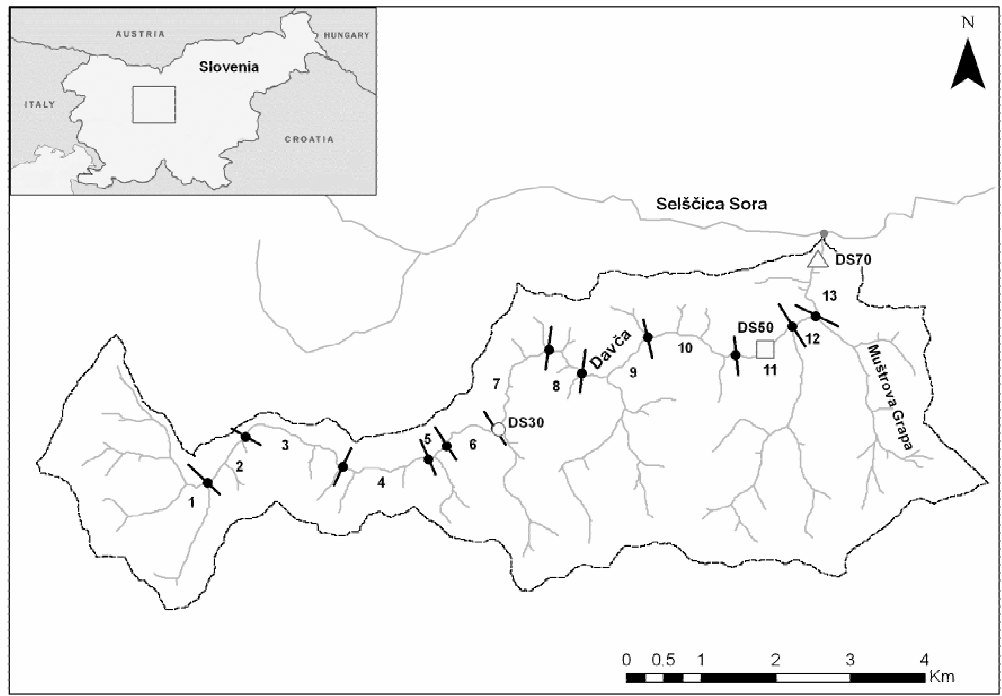

Figure 2: $\quad$ The Davča catchment with channel subdivision into 13 reaches and the cross-sections where peak discharge was estimated. The location map in the upper left corner shows the area affected by the flood of September 2007 in the Sora River basin.

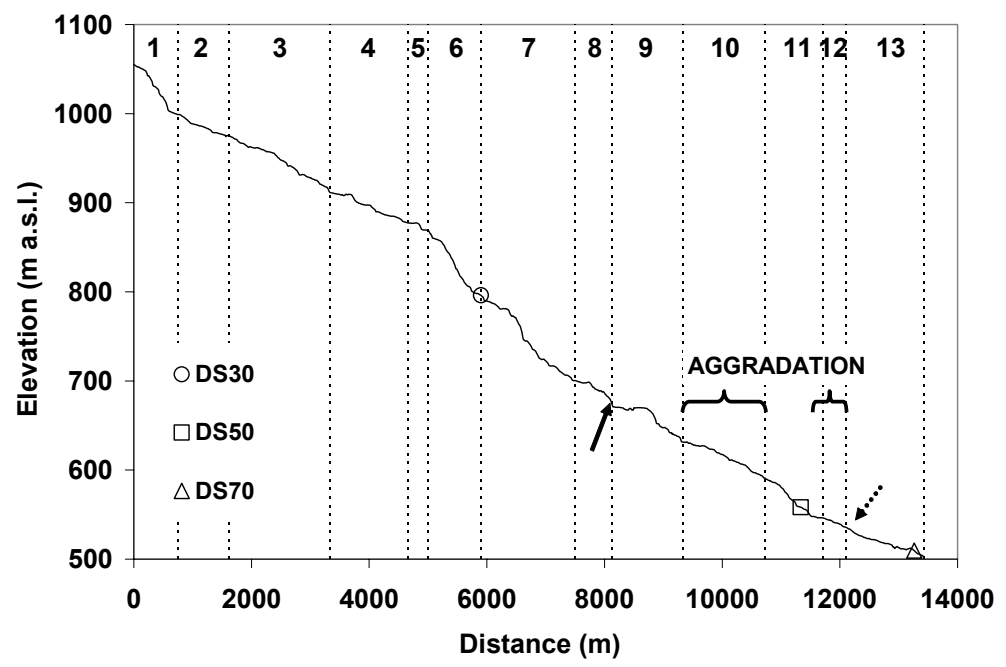

Figure 3: Longitudinal profile of the Davča Torrent. The solid row indicates the location of a major debris flow tributary, and the dotted line arrow the confluence with the Muštrova Grapa. The void symbols (circle, square, triangle) locate cross-sections where discharge was estimated (see also Fig. 2). 
rainfall, estimated recurrence interval about 250 yr [2]). The Davča main channel was separated into different reaches in order to describe the processes related to sediment and to large wood (LW) source, transport and deposition which took place during the flood event. The reaches are marked on the longitudinal profile (Fig. 3), which was derived from the DEM of the basin (12.5 $\mathrm{m}$ grid size), and therefore can be used for describing the channel bed at a large scale (i.e. $>100$ $\mathrm{m})$ only. Peak discharges were estimated from the flood marks, surveying with a total station 3 cross sections ( 2 in the Davča Torrent and 1 in its tributary Mustrova Grapa). For each cross section, the longitudinal bed slope and the highest flood marks were surveyed, and roughness coefficient was estimated based on grain size and channel morphology. The peak discharge was then calculated using the Manning-Strickler equation.

\section{Field observations}

Evidence of intense sediment transport were found at the headwaters (reach 1) below a 15-m high waterfall, and on a right tributary between the reaches 1 and 2 (hyper-concentrated flow with abundant LW recruited from the hillslopes). Overall, deposition of sediment and LW characterized the entire reach 2. Wood from upstream was trapped by the valley floor forest and by trees fallen into the channel as a consequence of bank erosion. The wide reach 2 ends at a road crossing where an eyewitness reported that the small bridge did not experience clogging during the flood, indicating how sediment and wood transport rates were not "excessive" here, despite a very high discharge (the flood marks are at
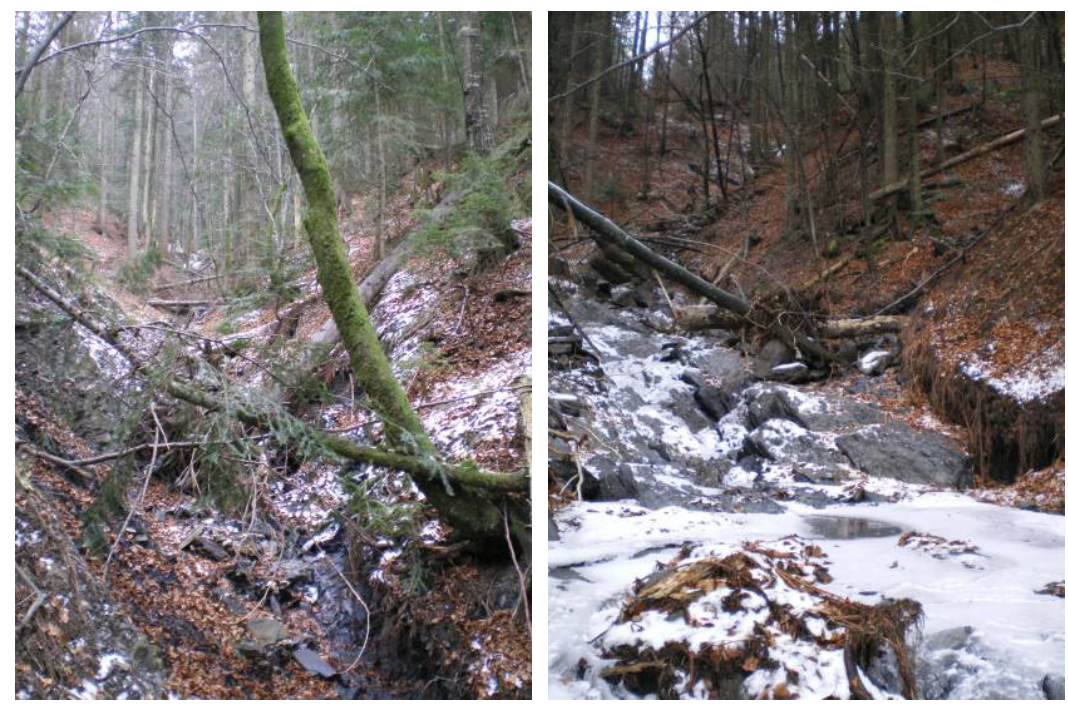

Figure 4: Steep tributaries incised to bedrock and recruited many LW elements which were too long to be transferred to the main channel. 
an elevation 2.5-3 times the bankfull stage) was already present in this upper part of the basin. Also in the next downstream reaches ( 3 and 4 ), the event did not cause major instabilities in the channel. As a consequence, these two reaches lack significant wood and sediment sources adjacent to channel. Furthermore, several steep right-hand tributaries surely experienced high flow rates, but sediments and LW delivered to the main channel were of minor influence. Most of them underwent incision (up to $1 \mathrm{~m}$ ) reaching the bedrock, with widespread bank erosion and associated recruitment of large trees, which could not be transported to the Davča (Fig. 4).

However, a road crossing (probably under-sized) between the reaches 4 and 5 likely caused backwater effects which led the channel to shift towards a forested floodplain just upstream of the bridge. Here many trees were recruited, further obstructing the bridge. In fact, there is evidence (lateral depositions, wood jams, Fig. 5(a)) that the main channel here spilled over the bridge. Downstream of it (reach 5), several huge LW jams (mostly composed of "fresh" trees) were trapped by standing trees on the floodplain and channel bends (Fig. 5(b)).

(a)
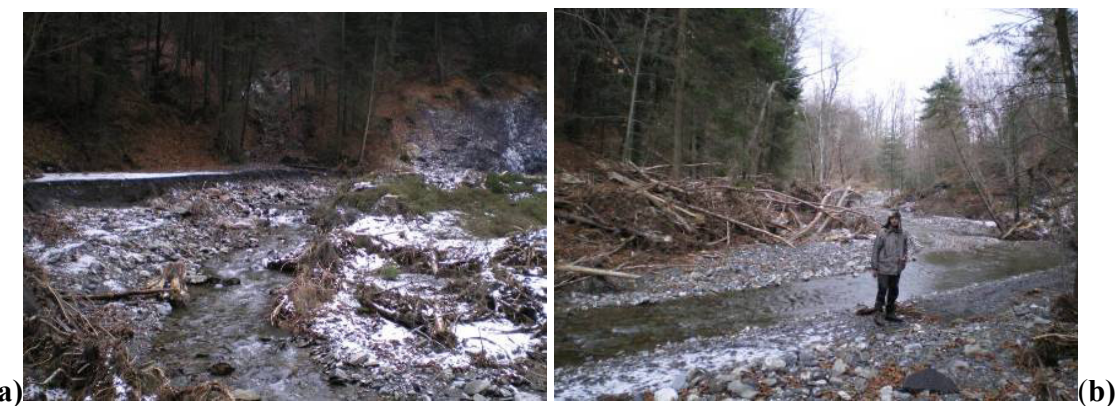

Figure 5: The effect of the bridge between reaches 4-5: (a) deposition and floodplain erosion upstream of the bridge; (b) high wood accumulations downstream of the bridge.

These jams are up to $2 \mathrm{~m}$ high, thus testifying a very high stage for a wide (15-20 m) cross-section. A possible flow surge issued from the bridge may be envisaged, but its effect must have been limited in length due to its small height and stored volume. Downstream of a check-dam (which separates reaches 5 and 6), the channel becomes steeper and then flows within a gorge over large boulders. Several large trees (beeches and spruces) fallen from the adjacent slopes are also present, but their transport was prevented by the narrow channel width. Between the reaches 6 and 7, the slope is lower, and the confinement of the channel on the right bank is less strict. Here the peak discharge was estimated to about $55 \mathrm{~m}^{3} \mathrm{~s}^{-1}$ (DS30 in Figs. 2-3, drainage area $9.8 \mathrm{~km}^{2}, 5.6 \mathrm{~m}^{3} \mathrm{~s}^{-1} \mathrm{~km}^{-2}$ ).

Reach 7 is morphologically comparable to reach 6 and features a small debris flow on a right-hand tributary. In the reach 8 , the main channel presents a milder slope and the valley floor widens considerably, with the presence of a grassy floodplain. A probable hyper-concentrated flow on a left-hand tributary delivered some sediment to Davča. In contrast, the next channel reach (9), flowing in a 
gorge, features relatively abundant sediment sources from the right bank (debris flows, landslides).

The reach ends at a bridge which was clogged by a probable combination of high water stage, intense coarse sediment transport, and floating LW supplied by nearby debris flows. Bridge clogging is indicated by upstream deposition of wood and sediment (Fig. 6). The backwater effect led to channel aggradation, forcing the stream to flow on the road.

(a)
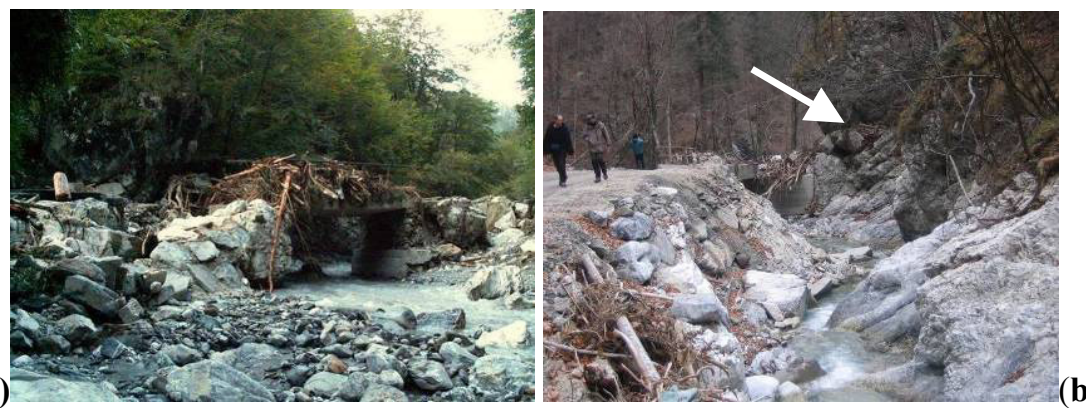

Figure 6: The bridge between reaches 9-10: (a) from downstream right after the flood; (b) from upstream two months later. Source for a: http://www.davca.si. The arrow indicates the flood marks.

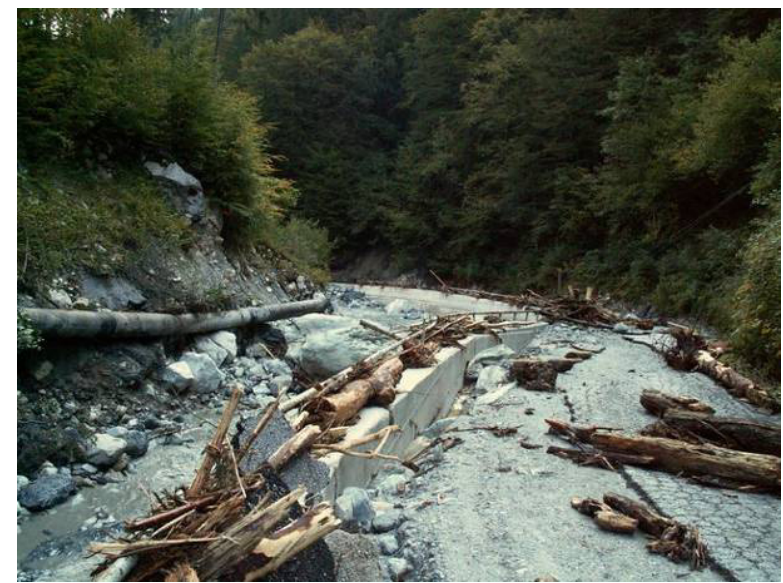

Figure 7: The narrow reach 11, featuring bank and bed erosion. Source: http://www.davca.si.

The road embankment and the bridge obstruction finally breached, probably causing a flow surge downstream where high-elevation $(>2 \mathrm{~m})$ marks were observed at channel banks. Reach 10 displays deposition of coarse sediment (up to $0.8-1 \mathrm{~m}$ in diameter) and further sediment inputs from the left slope (a small debris flow channel and several small landslides). Intense channel aggradation 
occurred where the valley widens, upstream of a bridge which collapsed and a huge LW jam was trapped upstream.

The steeper, narrower reach downstream (11, Fig. 7) was characterized by diffuse bank erosion and local bed incision. Peak discharge here (drainage area $21.4 \mathrm{~km}^{2}$ ) was estimated around $150 \mathrm{~m}^{3} \mathrm{~s}^{-1}$ (i.e., $7 \mathrm{~m}^{3} \mathrm{~s}^{-1} \mathrm{~km}^{-2}$, DS50 in Figs. 2-3).

Downstream, the Davča receives two important right-hand tributaries (Farji Potok and Muštrova Grapa), which did not show evidence of major channel changes and sediment transport, their bed still showing stable step-pool sequences. The peak discharge on the Muštrova Grapa just upstream of the confluence with the Davča (drainage area $4.2 \mathrm{~km}^{2}$ ) was evaluated to be $13 \mathrm{~m}^{3} \mathrm{~s}^{-1}$ $\left(3.1 \mathrm{~m}^{3} \mathrm{~s}^{-1} \mathrm{~km}^{-2}\right)$. Although lower than those observed in the upper Davča basin, these values indicate a high-magnitude flood. The bed stability of Farji Potok and Muštrova Grapa may be ascribed to a coarser surface layer and to a more developed bed structuring compared to the upper Davča.

Just upstream of the confluence with the Muštrova Grapa (reach 12), in correspondence of a widening of the valley floor, the Davča aggraded considerably; bridges were buried with sediments and wood and the flow invaded the road at left side (Fig. 8).

The bridge at the Muštrova-Davča confluence trapped some LW, but did not collapse because most of the floodwater was flowing on the road (Fig. 9). Part of the floating LW was then trapped by some trees at the road junction, while some accumulated against a building which was heavily damaged.

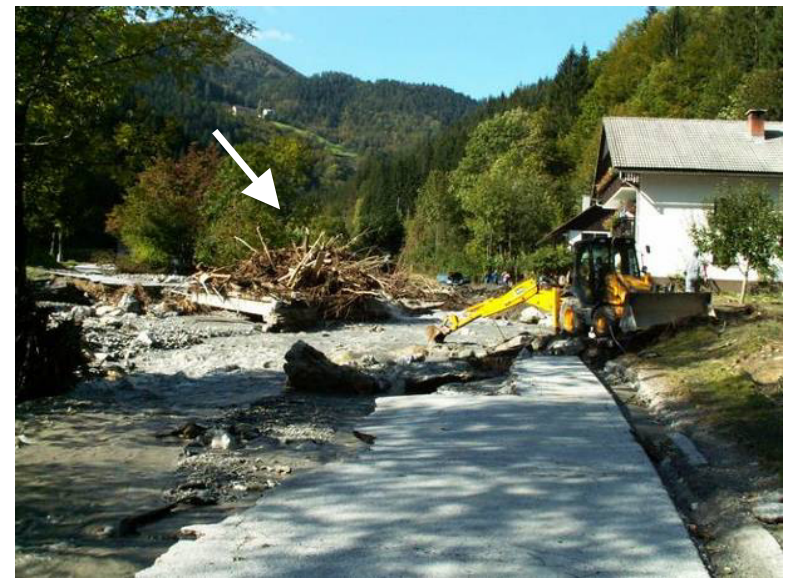

Figure 8: Channel aggradation and channel avulsion along reach 12, with a bridge clogged by LW. Source: www.davca.si.

Very coarse clasts (up to $0.8-1 \mathrm{~m}$ in diameter) were deposited upstream of the trees, and LW jams were up to $2 \mathrm{~m}$ high, both indicating very high stream power values. The total LW volume was estimated around $80 \mathrm{~m}^{3}$, but much had been already carried away during restoration works. The longest wood elements (up to $8 \mathrm{~m}$, roughly corresponding to channel width at the near upstream reaches) appeared to derive from riparian trees eroded by the flood, and the integrity of 

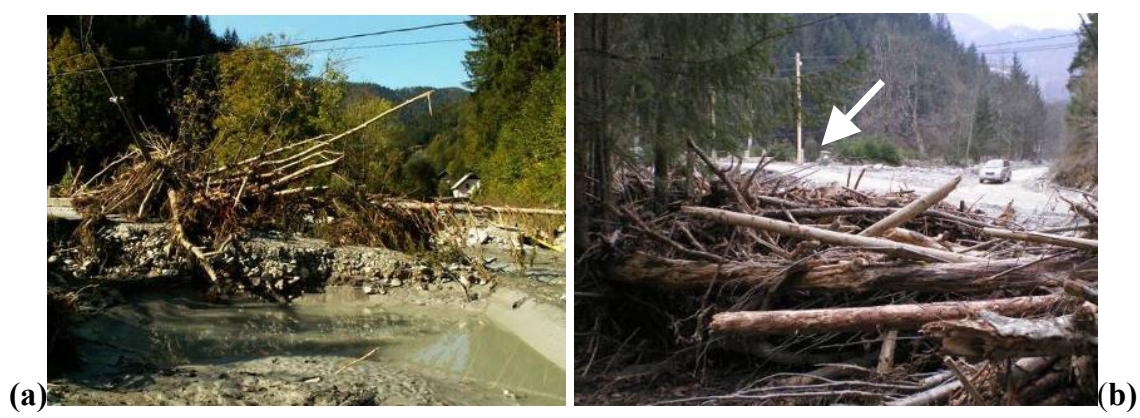

Figure 9: The Davča at the confluence with the Muštrova Grapa: (a) the bridge - not collapsed - from downstream right after the flood; (b) the LW jams trapped at the junction (November 2007). The arrow indicates the bridge location. Source for a: http://www.davca.si.

the bark cover hints to a brief transport distance, possibly just a reach length. In contrast, many shorter pieces showed clear signs of long residence time within the channel.

Only a minor volume of LW elements likely reached the channel downstream of the confluence with the Muštrova Grapa) and could be transported downstream (reach 13) towards the Selščica Sora. It is interesting to note that the peak discharge estimated for the Davča just upstream of the confluence with the Sora is less $\left(120 \mathrm{~m}^{3} \mathrm{~s}^{-1}, 3.8 \mathrm{~m}^{3} \mathrm{~s}^{-1} \mathrm{~km}^{-2}\right.$, DS70) than at the upstream cross-section DS50. Bearing in mind the large degree of uncertainty intrinsic in the flow peak estimates, their interpretation suggests either flood attenuation in the lower part of the stream (e.g., due to valley widening downstream of section DS50), a dambreak flow surge related to the obstructed bridge between reaches 9-10, or their combination.

\section{Conclusions}

Field observations have shown that large amounts of sediment and LW were mobilised within the basin, with a large variability of the intensity of supply processes. However, although a quantitative assessment of sediment and LW discharged by the Davča Torrent to the Sora River was not possible, the amount of sediment deposited on the floodplain at the confluence between these two streams appears to be small in comparison to sediment transport and LW mobilisation observed within the drainage basin. The short duration of the highest discharges, reported by local witnesses, probably contributed to limit the distances of transport, thus reducing sediment delivery to the outlet of the catchment. The post-flood survey gave evidence that transfer of large wood elements from the headwaters to the main channel was mostly associated to debris flows. In contrast, fluvial processes in small, low-order streams are not able to transport long, newly-recruited logs which remain stored in such 
channels. Other important wood sources were represented by forested floodplains in reaches where aggradation led to channel avulsion.

In conclusion, with regard to the considerable damages suffered in the Davča basin, they can be attributed to the combination of: i) very intense, infrequent precipitation; ii) locally large sediment and LW inputs, mostly from debris flows; iii) presence of critical narrow sections (road crossing); and, most importantly, iv) human occupation of valley areas naturally prone to flooding and channel aggradation.

\section{Acknowledgements}

This study was funded by the European Union's Sixth Framework Programme through the STREP Project HYDRATE, Contract GOCE 037024. The authors are grateful to the Environmental Agency of the Republic of Slovenia (ARSO) for providing the DEM of the studied basin and for the collaboration in field observations and in the interviews to eyewitnesses of the flood.

\section{References}

[1] Andreoli A., Comiti F. \& Lenzi M.A., Characteristic, distribution and geomorphic role of large woody debris in a mountain stream of the Chilean Andes. Earth Surface Processes and Landforms, 33(11), 1675-1692, 2007.

[2] ARSO (Agencija Republike Slovenije za Okolje), Poročilo o vremenski in hidrološki situaciji 18 septembra 2007. Governmental Report, www.arso.gov.si, 2007.

[3] Castiglioni, G.B., Note di commento alla carta dell'alluvione del novembre 1966 nel Veneto e nel Trentino-Alto Adige: effetti morfologici e allagamenti. In: Castiglioni G.B. (Ed.) Le calamità naturali nelle Alpi, Proc. XXI Congresso Geografico Italiano, Verbania, Vol 2(1), 269-290. 1974.

[4] Comiti F., Andreoli A., Lenzi M.A. \& Mao L., Spatial density and characteristics of woody debris in five mountain rivers of the Dolomites (Italian Alps). Geomorphology 78, 44-63, 2006.

[5] Costa J.E., Schuster R.L., The formation and failure of natural dams. Geological Society of America Bulletin 100, 1054-1068, 1988.

[6] Davies T.R., Scott B.J., Landslide dam-break flood hazard from the Callery Gorge, South Westland, New Zealand. Journal of Hydrology (NZ) 36(1), 1-13, 1997.

[7] Hancox G., McSaveney M.J., Manville V.R., Davies T.R., The October 1999 Mt Adams rock avalanche and subsequent landslide dam-break flood and effects in Poerua River, Westland, New Zealand. New Zealand Journal of Geology \& Geophysics 48, 683-705, 2005.

[8] Ishikawa, Y., Studies on disaster caused by debris flow carrying floating logs down mountain streams. SABO Department, Public Works Research Institute, Tsukuba, Japan, 1990. 
182 Monitoring, Simulation, Prevention and Remediation of Dense Debris Flows II

[9] Jakob M., Jordan P., Design flood estimates in mountain streams - the need for a geomorphic approach. Can. J. Civ. Eng., 28(3), 425-439, 2001.

[10] Lancaster S.T., Hayes S.K., Grant G.E., The effects of wood on debris flow runout in small mountainous watersheds. Water Resources Research 39(6):1168, doi:10.1029/2001WR001227

[11] Marchi L., Bain V., Intensive post-event campaign in the Selščica Sora river basin, Slovenia, after the flash flood of September 18, 2007. Hydrate Project IPEC Report, pp. 44, 2007.

[12] Marchi, L., Cavalli, M., Procedures for the Documentation of Historical Debris Flows: Application to the Chieppena Torrent (Italian Alps). Environmental Management, 40, 493-503, 2007. 